\title{
アクティブラーニングとしての協同学習の研究
}

\author{
関 田一彦 \\ (創価大学)
}

\section{A Study on Cooperative and Collaborative Learning as Active Learning}

\author{
Kazuhiko Sekita \\ (SOKA UNIVERSITY)
}

Active learning has become a widespread teaching method used in all levels of education since the government curriculum guidelines were revised. Nevertheless, active learning is an umbrella term that can include pedagogical approaches, course designs, various teaching strategies, and a number of learning activities. Therefore, depending upon the context of how it is used, the meaning of active learning will differ. There are two commonly used pedagogical approaches in active learning: cooperative learning and collaborative learning. These two approaches utilize very similar forms of learning activities and are thus often confused by teachers. Cooperative learning aims at relational development among students through successful learning experiences with one other. In contrast, collaborative learning aims at deepening students' understanding of concepts, as well as developing their learning skills by designing an interactive learning environment based on the theory of learning sciences. Although the form of learning activities is nearly identical, the purpose of these two approaches differs. This article suggests that researchers should design/conduct their research and interpret the results with an understanding of instructional purposes.

Key Words: active learning, cooperative learning, collaborative learning

アクティブラーニングは今，学習指導要領の改訂にともない，あらゆる校種で注目されている。ただ し，アクティブラーニングと一ロに言っても，教師中心と学習者中心に分けることも，知識定着型と能 力育成型に分けることも可能であり, 分けて考えることは, 研究の意義を高める上で有益である。アク ティブラーニングは能動的な学習を促す授業の総称であり，様々な教育方法やアプローチを内包する傘 概念である。したがって，アクティブラーニングそれ自体を研究するのは簡単ではない。実際，特定の 手法やデザインの方法や効果についての研究が主流である。中でも協調学習と協同学習は, アクティブ ラーニングに期待される，主体的な学び，対話的な学び，深い学びを具現化する上で有力である。協調 学習は対話的な学び，深い学びを研究する舞台である。協同学習は主体的な学び，対話的な学びの成果 を探るための機会を提供してくれる。研究者には, 同音異義語の混用を避ける意味でも, 自らの研究的 関心によって，協同学習と協調学習を使い分けることが望まれる。 キーワード : アクティブラーニング, 協同学習, 協調学習, 協働学習 


\section{はじめに}

筆者は協同学習の実践的研究者である。編集委員会 からは，アクティブラーニングが広がる中で，その代 表的な教育方法として協同学習に光が当たっているこ とを踏まえ，アクティブラーニングと協同学習の関連 などを視野に，この領域の研究動向を展望してほしい と依頼されたと認識している。

確かに今般の学習指導要領改訂の動きに合わせて, 教育現場では「アクティブ・ラーニング」が大流行し ている。ここ 2,3 年で「アクティブ・ラーニング」 を冠した図書・論文が実践書を中心に 100 点以上公刊 されている。まさに百花繚乱である。ただし，大半が 実践指南書であり，とてもすべてを渉猟・レビューで きるものではないし，そうすることが本誌の読者に とって有益とも思えない。

一方, 協同学習については, 半世紀を超える研究・ 実践の歴史がある。この教育心理学年報おいても, 過 去に杉江 (2004) が「教育心理学と実践活動」, 安永 （2009）が「展望」において，それぞれ論及している。 杉江 (2004) は協同学習研究と教育実践の結びつきを, 「様々な教育心理学の原理を統合して生まれた協同学 習（p. 156）」が多様な実践的課題に対応してきた例を 挙げながら論じている。それを踏まえて安永は, 特に 大学の授業改善に焦点を絞り, 協同学習の原理と技法 を用いた取り組みを紹介している。このように，すで に論じ尽された感のある協同学習を再び取り上げるこ とにいかなる意味があるのか，こちらもいささか自問 せずにおれない。

もう 1 つ, 筆者をいい意味で当惑させたのが，昨年 の年報に掲載された瀬尾（2016）の充実した「展望」 論文である。教授・学習の研究動向を扱う中で, 協同 学習関連の文献についてもしつかりしたレビューがな され，今回新たにレビューをする必要を感じさせない。

そこで, 本稿では少し思い切った言説を提示し, こ の分野の研究の方向について関心を高めてもらいたい と考えた。まず筆者のアクティブラーニングの捉え方 を述へ，次に協同学習と協調学習との関係を整理する。 そして，これからの協同学習のあり方について私見を 述べる。これらの作業の間に今年度の教育心理学研究 および日本教育心理学会第 58 回総会 (以下, 第 58 回総 会) 発表論文集に掲載された関連研究の動向分析を試 みる。なお，筆者は実際の発表を聞いてレビューを 行っているわけではないことを断っておく。
アクティブラーニングとアクティブ・ラーニング

教育現場では「アクティブ・ラーニング」と中黒を 入れた表記が, 文部科学省の公式表記として広く使わ れている。一方，この分野のオピニオンリーダーであ る京都大学の溝上慎一をはじめ, 行政用語との区別を 意識して, 中黒を入れず「アクティブラーニング」と 表記する研究者も多い。実際, 今回の総会発表論文集 でも中黒をつけない表記が一般的であり，本稿もそれ に倣う。

日本におけるアクティブラーニングは, 2012 年の

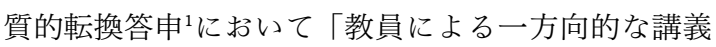
形式の教育とは異なり, 学修者の能動的な学修への参 加を取り入れた教授・学習法の総称」と解説され, 大 学教育の世界に広まってきた。これを溝上 (2014) は 「一方的な知識伝達型講義を聴くという（受動的）学 習を乗り越える意味での, あらゆる能動的な学習のこ と。能動的な学習には, 書く・話す・発表するなどの 活動への関与と, そこで生じる認知プロセスの外化を 伴う」と定義し, 傘概念としての概念整理を行ってい る。

当初, 大学教育改革のキーワードの 1 つされたが, 2014 年 11 月に行った中央教育審議会への諮問におい て, 下村文部科学大臣 (当時) は「課題の発見と解決 に向けて主体的・協働的に学ぶ学習」として,「アク ティブ・ラーニング」の導入検討を求めた。これを機 に, 初等中等教育の教員を対象にした導入・解説本が 溢れ始めた。さらに, 新指導要領策定に向けた教育課 程企画特別部会 (2015) の論点整理では「習得・活用・ 探求という学習プロセスの中で, 問題発見・解決を念 頭に置いた学び」「他者との協働や外界との相互作用 を通じて, 自らの考えを広げ深める, 対話的な学び」 「子どもたちが見通しを持って粘り強く取り組み, 自 らの学習活動を振り返って次につなげる, 主体的な学 び」を促進するのが「アクティブ・ラーニング」であ り，活動性（外見のアクティブさ）にばかり注目しない ように注意喚起がなされた。

論点整理の趣旨に沿えば，アクティブラーニングは， 瀬尾（2016）のレビューで「主体的・自律的な学習」と 「協同や相互作用を活かした学習」に分けられた研究 領域の，その両方にまたがるものと思われる。試みに，

平成 24 年 8 月中央教育審議会は「新たな未来を築くための 大学教育の質的転換に向けて〜生涯学び続け, 主体的に考元 る力を育成する大学へ〜」と題する答申を出し, 大学教育改 革の方向性を確認した。この答申を略して質的転換答申と呼 ぶ。 
主体的学習, 自律的学習, 能動的学習, アクティブ ラーニングをそれぞれ, 今回の第 58 回総会における 研究発表についてフリーワード検索機能を使って調べ ると, 順に 41 件， 29 件， 22 件， 27 件がヒットした。 初等中等教育関係者の間では注目を集めるアクティブ ラーニングではあるが，概念が大き過ぎて研究的関心 の焦点にはなりにくいのであろう。意外に件数は少な い。言い換えると，アクティブラーニングそれ自体で はなく，アクティブラーニングに分類される教授法や 授業デザインの効果 (e.g., 中山, 2016; 野崎, 2016; 吉田・南・ 松浦, 2016), あるいは学習活動への介入や学習過程の 分析 (e.g., 藤江・金沢, 2016; 町・橘・中谷, 2016; 大越, 2016; 篠 ケ谷, 2016) についての研究発表が大半である。

一方，第 58 回総会では, 自主企画シンポジウムに アクティブラーニングをテーマに冠した企画が 2 件 あった。金沢・藤江・栗栖・吉田・岡 (2016) の「アク ティブラーニングが教師の熟達化に及ぼす影響」と藤 江・寺本・河崎・後藤・高木 (2016) の「初等中等教育 段階の「アクティブ・ラーニング」への教育心理学的 アプローチ」である。どちらも，「アクティブ・ラー ニング」を学校現場がどのように受け入れ, 教員はど のような授業改善を行うのか, 学ぶ側より教える側に 関心が向いた課題提起の場となったと思われる。類似 の課題意識を持つ企画として，秋田他（2016）の「協 働学習における教師のあり方一認知・判断・実践知一」 がある。アクティブラーニングの代表的実践である協 働学習に取り組む教師の小グループを使う実践知，実 践者としての不安や状況判断を検討材料に, 協働学習 促進の方途を探る機会になったと思われる。

\section{アクティブラーニングと 教授学習パラダイムの転換}

溝上（2014）によれば，アクティブラーニングとい う傘概念は，教授学習パラダイムの転換という文脈の 中で, 時代的意味を持つという。まず, 教師主導の一 方的講義が (無自覚に) 促進してしまう受動的な学びを 改善するために開発・実践された, 学習者の能動的な 学びを促す授業方法をアクティブラーニングと呼ぶ段 階がある。これを教師中心のアクティブラーニングと する。次に, 学習者の能動性が喚起され, 学び手が主 役となる（したがって, 授業に扔ける学習活動の比重が教授活 動の比重より高くなる), 自主的あるいは主体的な学びが 前提となった授業を学習者中心のアクティブラーニン グとする。一口にアクティブラーニングといっても, 次元の異なる実践が混在しているのが，教授学習パラ ダイム転換の途上である今の教育現場である。この視
点に立てば，学習者中心のアクティブラーニングにお ける教授活動（教師のあり方）に，研究の関心が集まっ てきているのは当然なのかもしれない。

アクティブラーニングの研究を考える上で, もう 1 つ関心の集まる論点に, 学習の射程あるいは学習成果 がある。「浅い学び」と「深い学び」の対比（松下, 2015）とも関連するが, ここでは森（2016）の分類に 従って, 知識定着と能力育成を双極とするアクティブ ラーニングを考えてみたい。

系統性のある学問分野なら, 基礎基本の重要性は自 明であろう。したがって，学校教育において基礎知識 の定着とその定着度の測定は極めて重要である。ただ し, 学習者に基礎知識を習得させることが最終ゴール ではなく, 学習者が習得した知識を活用して，新たな 知識や価值を生みだすことが目指される（そのための基 礎知識である)。これはアクティブラーニングにおいて も，重要な前提である。アクティブラーニングを取り 入れた授業が, 知識の習得自体に重きを置くものか, 習得した知識の活用や新たな知識の構成・創造を意図 したものか，一口にアクティブラーニングといっても， (広げていえば, 知識を活用するための汎用的能力の育成も含 め) 目指す学習成果は異なるはずである。

試みに, 上記 2 つ視点を二軸として重ねて Figure 1 に表してみる。一口にアクティブラーニングと いっても，そしてアクティブラーニングを可能にする 種々の教授法や学習デザインといっても, 全てを同じ 指標でその学習効果を検討するのは難しいことが分か る。どのような文脈 (象限) での授業実践なのか, そ れによって学習者に暗に求められる学習成果が異なれ ば，そこで育成される能力や態度の到達水準に違いが 生まれる可能性は高いだろう。特に，授業実践を扱う 実践研究においては，授業者のねらいと採用される教 授法のマッチングを意識しておく必要もあろう。

\section{反転授業と $\mathrm{TAI}$}

具体的な例を挙げよう。アクティブラーニングとの 相性の良さも手伝って, 教育現場では反転授業の普及

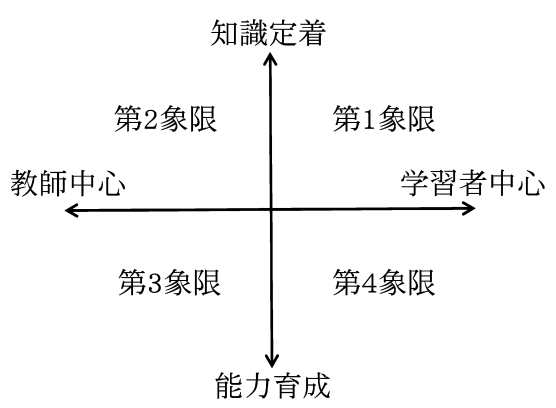

Figure 1 アクティブラーニングを捉える 2 軸 
が進んでいる。反転授業では ICT を活用することが 前提のように捉えられ, 教育工学の分野で成果発表が 盛んであるが, 教育心理学会総会においても 2014 年 度から，森ら（森・本田・溝上, 2015; 森・宗村・本田・溝上, 2014; 森・山田・杉澤・本田・溝上, 2016）が継続的に発表を 行っている。森他 (2016) は「反転授業だからこその 対面でのアクティブラーニングに注目（p. 433)」した いという。反転授業は知識の受容を事前学習として行 い，授業時には事前学習の成果を前提にしたアクティ ブラーニングを展開するのが一般的であろう。たとえ ば授業時にアクティブラーニング手法の 1 つであるジ グソー法を用いたとして，そこで行われるジグソー学 習は知識定着を意図したものと能力育成をねらったも のとに大別できる。益川（2016）は，前者のジグソー 法を正解到達型, 後者を知識構成型と呼んで区別して いる。Figure 1 に合わせると，前者は第 2 象限から 第 1 象限に向けての学習活動であり, 後者は第 3 象限 から第 4 象限に向かう学習が意図されてくると思われ る。

ICT を活用した事前学習における課題構造や作業 指示の特徵や効果自体に焦点を絞ることも可能だが, 事前学習と授業時の学習 (アクティブラーニング), さら には事後学習との関連, 組み合わせによる相乗効果に ついても, 教育心理学の視点や知見を活かした丁寧な 検討が求められるだろう。その意味で注目したいのが 深谷・植阪・市川（2016）の「教えて考えさせる授業

(TAI: Thinking after Instruction)」に関する発表である。

TAI（市川, 2004）は一斉指導による教師主導の授業 部分を残しつつ，理解定着のためのグループ活動と知 識構成・応用深化を意図したグループ活動を組み合わ せたアクティブラーニングである。加えて，授業の最 終段階では, 教師主導によって自身の学習活動を自己 評価させる。教師中心から学習者中心を経て教師中心 に戻る流れと，知識定着から能力育成へと進む流れが 融合した授業デザインは，アクティブラーニングとし て有力である。深谷・植阪・市川（2016）の研究は, TAI を構成する理解確認, 理解深化, 自己評価の 3 ステップから理解確認のステップを省いて，その影響 を調べたものである。それぞれの学習活動の組み合わ せ効果を点検し, TAI の構成の適切さを確認してい る。Figure 1 に合わせると, 第 2 と第 3 の象限を行 き来する学習活動が中心と思われる。

\section{Cooperative Learning (協同学習) と Collaborative Learning (協調学習)}

ない笑い話を聞いた ${ }^{2}$ 。彼が講師として招かれた校内 研修に参加していたある中学校の研究主任が, 彼に

「今までうちは，協同学習の導入を進めてきましたが， これからは視点を変えて，アクティブ・ラーニングを 推進していきます」と語ったという。協同学習とアク ティブラーニングを全くの別物として受け入れようと 迷走する現場の様子が窥える。傘概念であるアクティ ブラーニングを抽象度の高い言葉で説明すればするほ ど, 受け止める側の理解がまちまちになり, 従来から の様々なアプローチとの差異化に意識が向いてしまう のであろうか。

差異の強調については, Cooperative Learning（協 同学習) と Collaborative Learning (協調学習/協働学 習) との間でも議論になることが多かった（e.g., 溝上, 2014; 関田・安永, 2005)。「協調」は別として,「協同」と 「協働」は，同音の類義語である。会話の中での聞き 分けは難しい。「きょうどう」という発音に対応する のは, 他にも「共同」「共働」など, 厳密に使い分け るのが難しい同音類義語が多い。日本語特有の問題で ある。そのため, 協同学習と協働学習の異同について, 教育現場は困惑してきた。

特に, 初等中等教育の現場では, 1990 年代以降, 東京大学 (当時) の佐藤 学を中心にする, 「学びの共 同体」と呼ばれる学校改革のアプローチが広く全国に 展開した（佐藤, 2012)。このなかで, 生徒同士の学び合 いを重視した協同的学び (=協働学習) という使われ方 が広まった。(余談だが, ここ 10 年ほどの間に, 上越教育大学 の西川 純が主導する『学び合い』アプローチが広がり, 二重括 弧の学び合いと称して,「学びの共同体」アプローチと共に広 がった「学び合い」との区別を求めている。)

第 58 回総会の発表論文についてフリーワード検索 機能を使って調べると, 協同学習 35 件, 協働学習 31 件, 協調学習 15 件が検索された。協調学習と協働学 習は, どちらもCollaborative Learning を意味して いる。協同学習, 協働学習どちらのキーワードからも ヒットする発表もあり, 数の上からは Collaborative Learning に関する研究が趨勢と思われる。また，協 働学習は半数が福祉・保育・看護, 特別支援教育, そ して教育相談の内容を扱った発表の中で使われており， 様々な分野でのグループを使った学習活動に広く用い られているようである。

私見だが，最近，R. K. Sawyer 編（2014大島・森・秋 田・白水監訳 2016) 『学習科学ハンドブック第二版第 2 巻』が翻訳出版された。その「全巻まえがき」に,

杉江修治（personal communication, 2016 年 10 月) 
「今回の翻訳はすべての内容をできるかぎり正確に翻 訳した。(中略) 広くその専門に詳しい国内の研究者 を総動員して，可能なかぎりわかりやすい翻訳を心が けた。(p. i)」と 4 名の監訳者（大島 純, 森 敏昭, 秋田喜代 美, 白水 始) が連名で謳っている。2009 年に翻訳され た第 1 版では，一部に「協働」という言葉が混用され ていたが，この第 2 版の翻訳では「協調」に統一され ている。これを機に，少なくとも学習をテーマとする 領域では, Cooperative learning を協同学習, Collaborative learning を協調学習と表記することで合 意形成できないものだろうか。「きょうどうがくしゅ う」の同音異義語が複数存在する日本においては，現 場の混乱回避に多少とも役立つと考える。

\section{協同学習と協調学習の研究的関心}

仮に，訳語を分けることで漢字表記の上からは区別 できたとして，それぞれの学習が意味するところに， ぞれほどの違いがあるのか定かではない。単純化して 言えば, 協調学習は, 社会構成主義に基づく学習論を 背景に持つ。一方，協同学習は，グループダイナミク 又研究を背景に持つ。依って立つ理論的背景が異なれ ば，なにがしかの違いはあるはずである。1950 年代 から発展してきたグループダイナミクス研究よりも, 1980 年代以降, 急速に研究が進んだ社会構成主義に 基づく認知・学習研究に関心が集まるのは自然なこと であろう。協同学習は，一見すると，その研究的関心 のピークを過ぎた古い研究領域になってしまったよう にも見える。

協調学習の研究によって, 認知的側面を中心とした 学びのプロセスや学習者間の認知的相互作用が明らか になる。それは協同学習を行う場合でも有益な知見で あり, その意味で, 協調学習の研究はむしろ協同学習 を発展させる基礎研究と位置付けてもいいかもしれな い。そして一方, 協調学習の側からは, 協同学習が蓄 積してきた相互作用を生起させるぺアやグループ活動 の手法を使って, 研究を進めることができる。その意 味では, 協同学習は研究のための道具箱の役割を果た しているといえるかもしれない。実際，協調学習の実 践手法を集めたガイドブックには，たくさんの協同学 習の技法が載っている (e.g., Barkley，Cross，\& Major, 2005 安永監訳 2009)。

学習科学が台頭する中で，ますます注目されるのが 協調学習である。飯窪 (2016) は協調的な問題解決と いう「アクティブラーニングで私たちが育てたいのは, 答えの受け手ではなく，作り手である (p. ii)」と宣言 する。学習者は仲間（他者）との相互作用を通じてど のように知識を習得し，新たな知識を創発するのかと
いう，認知的プロセスの研究が協調学習の基盤である。 一方，学習者は仲間との関係をどのように結び，維 持・促進し，あるいは終結させるのか，そのプロセス をどのように感じ，意味づけ，人間的成長の糧とする のか，といった広範な研究的関心が交差する協同学習 は，学習活動を共にする他者との関係をより生産的・ 建設的なものにする方途を探っていく。どのように学 んだか（知識を構成したか，構成できるようになったのか）と いう研究的関心と協調学習は結びつく。一方, その学 びは関係性をどのように変化・向上させたのか（理解の 深まりは相手にとってどのような意味があったのか）という研 究的関心と協同学習は結びつく。

こうした視点から第 58 回総会発表論文集を眺める と, 中山 (2016), 真田 - 栗原 (2016), 山地・川越 (2016) などが協同学習的な研究として挙げられる。 真田・栗原（2016）は協同学習場面における相互作用の 規定要因として学級集団内の地位に着目し，小学生を 対象にその影響を調べている。数年前に流行ったス クールカーストなども集団内の地位の問題であり, 協 同学習の効果促進を考える上で大切なテーマである。

中山（2016）は大学生を対象に行った協同学習が, 学期の進行に伴う学習者の他者理解に及ぼす影響につ いて検討している。山地・川越（2016）の研究では大学 生を対象に，協同学習ではなくグループ学習の影響を 対人関係傾向の変化として捉えている。この 2 本に共 通するのは, 協同学習のような対人関係の変化が想定 される学習活動（アクティブラーニング）の影響を，様及 な指標によって測ろうとしている点である。ただし， 大学生のように，同時期に複数の科目で異なる授業方 法を異なるクラスメイトと共に体験する調査対象を 使って, 特定の科目の影響をどこまで適切に測れるか は方法上の課題として残る。

協調学習の研究例としては, 先述の TAIに関連す るが，深谷他（2016）の実践研究について触れておき たい。理解確認・理解深化の要となる仲間同士の「教 えあい」の質を高める介入を, 高校生を対象に行った 結果の分析である。教えあいの成果を高める学習方略 を高校生たちは必ずしも十分に使っていないことが予 備実践で確認された。そこで，推奨したい方略の意義 を解説する講演を足場かけとして用意し, 日常の学習 活動における方略使用を促した。「聴き手の説明（教元 た後に, 聴き手に内容を説明させて理解度を確かめる)」など， 使用回数が増えない方略もあったが, 概ね介入の効果 が認められた。この介入を計画する際, 「教授一学習 スキーマ」の変容が意図された。すなわち「断片的知 識や解法手続きを一方的に教える」一「教師（教元手） 
から一方的に聞いて学ぶ」という行動を交互に行うの が「教えあい」である，という観念を変えさせようと 働きかけたのである。そして，「関連付けられた知識 を相互に教えあう」ために有効な学習方略の使用を促 そうとしたのである。ペアやグループでの教えあいの 質を高める指導上のポイントが 1 つ明らかになったと 思われる。

\section{協同学習の学校教育的意義}

もともと日本はアメリカと異なり, 学校行事や生活 指導など, 学校を生活の場としての集団指導が重視さ れ，しかもそれは担任教師を中心になされてきた。学 習指導は学級づくり(つまり,クラスという集団を前提とし た授業方法）を前提に行われ，学級王国と呼ばれるほど 強い凝集性を示してきた。こうした学校文化の下で発 展してきた日本の協同学習は, 学習目標 (認知領域) と 態度目標 (非認知的・社会的領域) の同時学習を指向した 学習指導法として実践を重㸚てきた（杉江, 2004)。つま り, 協同学習は知識・理解の定着と共に, 協働性・社 会性を育む教育方法として現場に根付いており，これ は, 態度形成まで学習成果の範疇とする「アクティ ブ・ラーニング」が目指すところと大きく重なる。

他者と協調して学ぶためには, 自身の学習活動を律 することが求められる。そして, 他者との協調を確か にするには, 他者と協同する意味を理解し, 自身の学 習を主体的に選択・決定することが求められる。主体 的であるとは，教員からの指示の有無にかかわらず， 自身の探求心あるいは信念や価值観に従って課題に取 り組み，時として課題の要求を越えた，深いあるいは 広い学習を選択的に進められるということである。こ のような協調／協働を支える文脈を協同学習は提供す るのである。

今後, 初等・中等教育の現場では新学習指導要領に 基づき, 主体的, 対話的, 深い学び，という 3 つの キーワードに即して現場の実践は進むであろう。そし て, その実際を明らかにし，あるいはその生起・伸展 のメカニズムや促進の方途を探る研究への要請は高ま るであろう。異論はあろうが，少なくとも日本におい ては, 協同学習と協調学習は相補的な関係にあり, ど ちらかが優れている，あるいは遅れているといった対 立的なものではない。

\section{まとめ}

アクティブラーニングは傘概念であり，それ自体の 効果を検討するのは，又夕分析のようにいくつかの手 法を束ねて，その効果について比較する研究が必要だ
ろう。言い換えれば，アクティブラーニングは単一の 手法やアプローチではないので, アクティブラーニン グに分類される特定の手法やアプローチの効果検証, 改善・精緻化を個々に行う研究，あるいは新たな手法 の開発・提案を行う研究が当面は主流になろう。

その際，協調学習と協同学習は様々な研究のプラッ トフォームになるだろう。学習科学の知見を活かして 設計される協調学習は, アクティブラーニングにおけ る学習の質を研究する場を私たちに提供してくれる。 研究成果の実践への適用と, 実践を通じた研究課題の 発見, という往還が協調学習の普及を進めていくだろ う。そして, 協同学習が行われる教室は社会性・協働 性の涵養, 主体性・能動性の促進, 自己理解・自己受 容や共同体感覚の醸成といった, 学習を通じた人間的 成長を研究する格好の場となる。私たちは, 研究を通 じて明らかにしたい事柄（研究的関心）によって，協調 学習と協同学習を使い分けることになるだろう。

\section{引用文献}

秋田喜代美 - 一柳智紀 - 石橋太加志 - 児玉佳一 - 松木 健一・中谷素之 (2016). 協働学習に抢ける教師の あり方一認知・判断 - 実践知 日本教育心理学会第 58 回総会発表論文集, 120-121.

Barkley, E. F., Cross, K. P., \& Major, C. H. (2005). Collaborative learning techniques: A handbook for college faculty. San Francisco: Jossey-Bass. (バークレイ, E. F., クロス, K. P., \&メジャー, C. H. 安永 悟（監訳）（2009）. 協同学習の技法一大学教 育の手引き ナカニシヤ出版)

藤江浩子・金沢 緑 (2016). 協同的な学びによる思考 力・表現力の向上をめざした理科授業一授業設計・ 評価マトリクスを用いて 日本教育心理学会第 58 回総会発表論文集, 700 .

藤江康彦 - 寺本貴啓 ・ 河崎美保 - 後藤頻一・高木正之 (2016). 初等中等教育段階の「アクティブ・ラーニ ング」への教育心理学的アプローチ 日本教育心理 学会第 58 回総会発表論文集, 106-107.

深谷達史・植阪友理・市川伸一 (2016).「教えて考元 させる授業」の効果検証一中学生に対する理科の実 験授業から 日本教育心理学会第 58 回総会発表論 文集, 509 .

深谷達史・植阪友理・田中瑛津子・篠ケ谷圭太・西尾 信一・市川伸一 (2016). 高等学校に打ける教えあ い講座の実践一教えあいの質と学習方略に対する効 果 教育心理学研究, 64, 88-104. doi:10.5926/jjep. 64.88 
市川伸一 (2004). 学ぶ意欲とスキルを育てる一いま 求められる学力向上策 小学館

飯窪真也 (2016). はじめに 三宅なほみ・東京大学 $\mathrm{CoREF}$ ・河合塾（編著）協調学習とは一対話を通 して理解を深めるアクティブラーニング型授業 北 大路書房

金沢 緑・藤江浩子・栗栖裕司・吉田順一・岡 直樹 (2016). アクティブラーニングが教師の熟達化に及 ぼす影響一授業設計・評価マトリクスを用いて 日 本教育心理学会第 58 回総会発表論文集, 30-31.

町岳・橘春菜 - 中谷素之 (2016). 達成目標促進と 授業実践型相互教授の効果 (1) 一課題理解の質に 及ぼす影響 日本教育心理学会第 58 回総会発表論 文集, 437 .

益川弘如 (2016). 知識構成型ジグソー法 溝上慎一

(監) 安永 悟・関田一彦・水野正朗（編著）アク ティブラーニングの技法・授業デザイン（pp. 6787）東信堂

松下佳代 (2015). ディープ・アクティブラーニングへ の誘い 松下佳代・京都大学高等教育研究開発推進 センター(編著) ディープ・アクティブラーニング (pp. 1-27) 勁草書房

溝上慎一 (2014). アクティブラーニングと教授学習 パラダイムの転換 東信堂

文部科学省教育課程企画特別部会 (2015). 教育課程 企画特別部会における論点整理について（報告） http://www.mext.go.jp/b_menu/shingi/chukyo/ chukyo3/053/sonota/1361117.htm

森 朋子 (2016). アクティブラーニングを深める反転 授業 安永 悟・関田一彦・水野正朗（編著）アク ティブラーニングの技法・授業デザイン（pp. 88 -109) 東信堂

森 朋子・本田周二・溝上慎一 (2015). 大学教育の反 転授業デザイン一授業観察からその効果を考察する 日本教育心理学会第 57 回総会発表論文集, 232.

森 朋子・宗村広昭・本田周二・溝上慎一 (2014). 大 学における反転授業の実証的研究一アクティブラー ニングの観点から 日本教育心理学会第 56 回総会 発表論文集, 198 .

森 朋子・山田剛史・杉澤武俊・本田周二・溝上慎一 (2016). 反転授業における学生の学びの多様性一教 育統計学の授業を例に 日本教育心理学会第 58 回 総会発表論文集, 433 .

中山留美子 (2016). 協同学習の進行に伴う学びへの
態度の変化一問題解決学習を取り入れた大学授業を 対象として 日本教育心理学会第 58 回総会発表論 文集, 348 .

野崎秀正 (2016). 協同型授業における仲間との学習 経験が児童の学習観に及ぼす影響 日本教育心理学 会第 58 回総会発表論文集, 325 .

大越健斗 (2016). ペアでの平面図形の証明過程にお けるつまずきの分析一分野特性と学習形態からの影 響に注目して 日本教育心理学会第 58 回総会発表 論文集, 771 .

真田穣人・栗原慎二 (2016). 小学校授業における児 童同士の相互作用と学級集団内地位との関連 日本 教育心理学会第 58 回総会発表論文集, 644 .

佐藤 学 (2012). 学校を改革する一学びの共同体の構 想と実践 岩波書店

Sawyer, R. K. (Ed.) (2014). The Cambridge handbook of the learning sciences (2nd ed.). Cambridge: Cambridge University Press. (ソーヤー, R. K. (編) 大島 純 - 森 敏昭 - 秋田喜代美 - 白水 始 (監訳) (2016). 学習科学ハンドブック 第二版第 2 巻 効果的な学びを促進する実践/共に学ぶ 北 大路書房)

関田一彦・安永 悟 (2005). 協同学習の定義と関連用 語の整理 協同と教育, 1, 10-17.

瀬尾美紀子 (2016). 21 世紀の学習・教育実践に期待さ れる教授・学習研究 教育心理学年報, 55, 68-82.

篠ヶ谷圭太 (2016). 相互作用時のモニタリングの役 割一活動中の発話との関連の検討 日本教育心理学 会第 58 回総会発表論文集, 507.

杉江修治 (2004). 協同学習による授業改善 教育心 理学年報, 43，156-165. doi:10.5926/arepj 1962.43.0 _156

山地弘起・川越明日香 (2016). 対人関係傾向とアク ティブラーニングの効果一公的自己意識の影響に着 目して 日本教育心理学会第 58 回総会発表論文集, 173.

安永 悟 (2009). 協同による大学授業の改善 教育心 理学年報, 48, 163-172. doi:10.5926/arepj1962.48.0 163

吉田卓司・南 学・松浦 均 (2016). ジグソー法を用い た高校数学の授業効果一動機づけ, 学習観及び内容 理解への影響 日本教育心理学会第 58 回総会発表 論文集, 778 . 